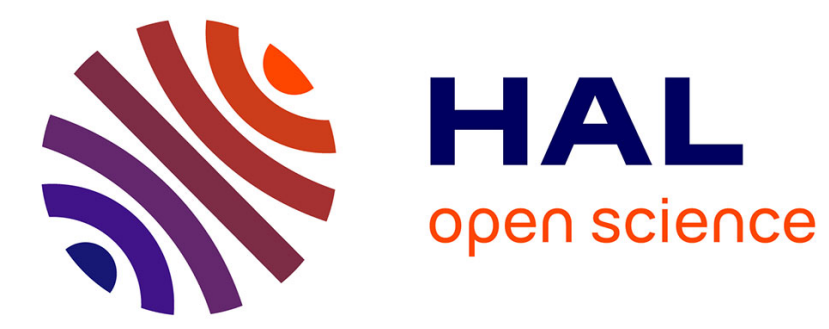

\title{
Solvent-Free Electrolytes for Electrical Double Layer Capacitors
}

\author{
Léo Nègre, Barbara Daffos, Pierre-Louis Taberna, Patrice Simon
}

\section{To cite this version:}

Léo Nègre, Barbara Daffos, Pierre-Louis Taberna, Patrice Simon. Solvent-Free Electrolytes for Electrical Double Layer Capacitors. Journal of The Electrochemical Society, 2015, 162 (5), pp.A5037-A5040. $10.1149 / 2.0061505 j$ jes . hal-01432155

\section{HAL Id: hal-01432155 \\ https://hal.science/hal-01432155}

Submitted on 11 Jan 2017

HAL is a multi-disciplinary open access archive for the deposit and dissemination of scientific research documents, whether they are published or not. The documents may come from teaching and research institutions in France or abroad, or from public or private research centers.
L'archive ouverte pluridisciplinaire HAL, est destinée au dépôt et à la diffusion de documents scientifiques de niveau recherche, publiés ou non, émanant des établissements d'enseignement et de recherche français ou étrangers, des laboratoires publics ou privés. 


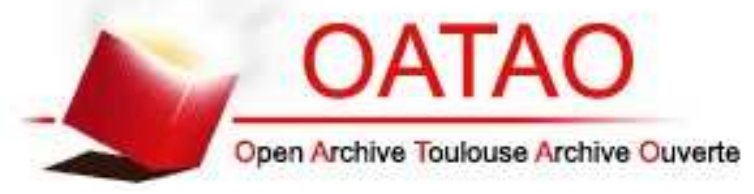

\section{Open Archive TOULOUSE Archive Ouverte (OATAO)}

OATAO is an open access repository that collects the work of Toulouse researchers and makes it freely available over the web where possible.

This is an author-deposited version published in : http://oatao.univ-toulouse.fr/ Eprints ID : 16800

To link to this article : DOI : 10.1149/2.0061505jes

URL : http://dx.doi.org/10.1149/2.0061505jes

To cite this version : Negre, Léo and Daffos, Barbara and Taberna, Pierre-Louis and Simon, Patrice Solvent-Free Electrolytes for Electrical Double Layer Capacitors. (2015) Journal of The Electrochemical Society (JES), vol. 162 (n ${ }^{\circ}$ ). pp. A5037-A5040. ISSN 0013-4651

Any correspondence concerning this service should be sent to the repository administrator: staff-oatao@ listes-diff.inp-toulouse.fr 


\title{
Solvent-Free Electrolytes for Electrical Double Layer Capacitors
}

\author{
L. Nègre, ${ }^{a, b}$ B. Daffos, ${ }^{a, b}$ P. L. Taberna, ${ }^{a, b}$ and P. Simon ${ }^{a, b, *, z}$ \\ ${ }^{a}$ Laboratoire CIRIMAT, UMC CNRS 5085, Université Paul Sabatier Toulouse III, 31062 Toulouse Cedex, France \\ ${ }^{b}$ Réseau sur le Stockage Electrochimique de l'Energie (RS2E), FR CNRS 3459, France
}

\begin{abstract}
A mechanically-stable non-aqueous inorganic gel polymer electrolyte that is based on association of sol-gel agents and Ionic Liquid is considered here for application in solid-state solvent free supercapacitors. The first part is devoted to the electrochemical characterization of the ionogel bulk properties. In the second part, an electrochemical cell using activated carbon as active materials and the new ionogel electrolyte has been characterized over a wide temperature range using cyclic voltammetry and electrochemical impedance spectroscopy. The use of high IL content (70\%) has led to an increase of both the operating voltage window (up to $3 \mathrm{~V}$ ) and the electrolyte ionic conductivity (around $4.7 \mathrm{mS} / \mathrm{cm}$ ). The resulting double layer capacitance of the microporous activated carbon device was found to be as high as $80 \mathrm{~F} / \mathrm{g}$; even more important, this quasi solid electrolyte works well over a wide temperature range (namely, from -30 to more than $80^{\circ} \mathrm{C}$ ).
\end{abstract}

DOI: $10.1149 / 2.0061505$ jes

Electrochemical Capacitors (ECs), also known as supercapacitors, have now reached the technical maturity for complementing- and sometimes replacing- batteries in a large range of applications from power electronics to transportation such like in hybrid electric vehicles or trams. ${ }^{1}$ They are currently used for high power delivery for few seconds or tens of seconds as well as for energy recovery (braking energy in cars, kinetic energy in cranes or elevators...). Despite the abounding research on pseudocapacitive materials with promising performance ${ }^{2-6}$ Electrochemical Double Layer Capacitors (EDLCs) using porous carbons as active material are still by far the most commercialized devices. ${ }^{7}$ One of the most important challenge the technology is currently facing is the improvement of the maximum energy density, which depends from the capacitance and the cell voltage through the equation 1

$$
E=\frac{1}{2} C \cdot V^{2}
$$

Where $\mathrm{C}$ stands for the capacitance $(\mathrm{F}), \mathrm{V}$ the cell voltage $(\mathrm{V})$ and $\mathrm{E}$ the energy $(\mathrm{J})$.

While the improvement of the capacitance has led to important discoveries in the ion transport and adsorption in confined pores of nanoporous carbons, ${ }^{8,9}$ the increase of the cell voltage is still today limited by the electrolyte stability windows. During long time, conventional electrolytes based on acetonitrile or propylene carbonate solvents have been used in combination with ammonium cations and fluoride anions. ${ }^{4}$ More recently, mixtures of various carbonate-based solvents used in Li-ion batteries have been proposed by Lust's group, with an increase of the supercapacitor cell voltage up to $3 \mathrm{~V} .{ }^{10}$ However, such electrolytes are known to be highly sensitive to moisture and the formation of a Solid Electrolyte Interphase (SEI) in carbon micropores, blocking further ion accessibility these pores. ${ }^{11}$

Another strategy is to design new electrolytes or solvents. ${ }^{12}$ Such an approach is certainly one of the most promising in terms of performance improvement but, at the same time, the most complex since new solvents or electrolytes must match multiple criteria (conductivity, viscosity, electrochemical stability...). Interesting work was recently done by A. Balducci et al. has recently proposed the use of adiponitrile for replacing acetonitrile. ${ }^{13,14}$ Although cell voltage up to $3.5 \mathrm{~V}$ were demonstrated with a decent stability during cycling, adiponitrile-based electrolytes suffer from a limited conductivity (4 $\mathrm{mS} / \mathrm{cm})$ and a high viscosity (6 $\mathrm{mPa} . \mathrm{s})$ at room temperature restricting their use to temperature higher than $0^{\circ} \mathrm{CC}^{13}$

The same restriction applies to Ionic Liquids (ILs) that are solventfree electrolytes, liquid at room temperature. The large electrochem-

*Electrochemical Society Active Member

${ }^{\mathrm{z} E}$-mail: simon@chimie.ups-tlse.fr ical voltage window (up to $4 \mathrm{~V}$ ) ${ }^{10}$ they can offer is balanced by their limited ionic conductivity and high viscosity at room temperature. ${ }^{4}$ As a result, porous carbon-based supercapacitors using neat ILs as electrolytes show very good electrochemical performances at temperatures higher than Room Temperature (RT), ${ }^{15,16}$ but fail in a large extent to maintain such performance below RT.

Protic Ionic Liquids (PILs) are ILs where a proton can be transferred from a Brönsted acid to a Brönsted base..$^{17}$ PILs are easier to synthesize, less viscous and show higher conductivities than aprotic ionic liquids. ${ }^{18}$ As a result, capacitance beyond $100 \mathrm{~F} / \mathrm{g}$ were reported for porous carbons at room temperature, with decent low temperature behavior with about $40 \%$ loss at $-10^{\circ} \mathrm{C} .{ }^{19}$ However, the easy proton transfer narrows the electrochemical voltage windows because of redox reactions, resulting in maximum voltage of about $2 \mathrm{~V} .^{20}$

In summary, none of the approaches described above has been successful for designing electrolytes that fully match all the criteria of the ideal - high conductivity, low viscosity, large voltage window and operation temperature range - and it is a safe bet that we are not that close to reach the goal.

However, ILs being solvent-free, nonvolatile and nonflammable electrolytes, they are very appealing candidates for replacing the conventional solvent-based liquid electrolytes, including the one containing acetonitrile. Indeed, the low boiling point $\left(81.6^{\circ} \mathrm{C}\right)$, high vapor pressure $\left(9.7 \mathrm{kPa}\right.$ at $\left.20^{\circ} \mathrm{C}\right)$ and high flammability (flash point $=2^{\circ} \mathrm{C}$ ) of acetonitrile is a source of concern in some applications, from the safety point of view; replacing the acetonitrile with a solvent-free electrolyte would thus first alleviate such safety issues. Going further, moving from liquid to solid electrolytes is also of great interest in the aim of solving packaging issues, corrosion, self-discharge or leaks. ${ }^{18,21}$ The key issue to tackle in this aim is to achieve high mechanical stability while retaining high ionic conductivity. Last but not least a good contact at electrolyte-electrode interphase is required, in order to preserve decent gravimetric capacitance temperature behavior below RT. This is particularly true for EDLCs where high surface area carbons are used as active materials.

In this paper, we will present results about the synthesis and characterization of a quasi-solid-state supercapacitor using ionogel solvent free electrolytes, whose concept was recently pioneered by Brousse's group. ${ }^{22}$ Such devices could efficiently replace liquid-based systems for improving the safety, corrosion and the packaging of supercapacitors, thus extending the range of applications of these systems.

\section{Experimental}

Ionogel synthesis. - Ionogels were achieved by trapping into a functionalized silica an ionic liquid (1-ethyl-3-methyl imidazolium bis(trifluoromethanesulfonylimide), EMITFSI 99.9\% (purchased 
(a)

\begin{tabular}{|l|l|l|l|}
\hline Component & TEOS & TMOS & FA \\
\hline Volume \% & 2 & 2 & 5 \\
\hline
\end{tabular}

(b)

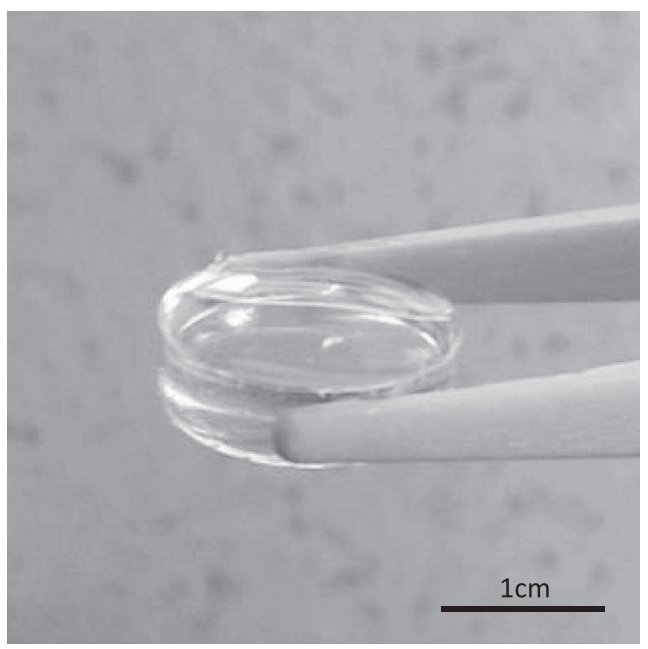

Figure 1. Volume ratio for ionogel sol synthesis (a) and ionogel lingot picture (b).

from Sovlionic, France) through a sol-gel process. An organic based sol-gel route was preferred in this work to create a very fine porosity (G.Sharp et al $)^{23}$ consisting in a mixture of two silica precursors (TetraEthyl OrthoSilicate and TetraMethyl Ortho Silicate, from Sigma Aldrich) with Formic Acid (FA, 98\% purchased from Arcos Organics) as a catalyst agent. FA was mixed to the silica precursors under moderate stirring $(200 \mathrm{rpm})$ at $40^{\circ} \mathrm{C}$ during 20 minutes to initiate sol-gel hydrolysis reactions. Then 70\%vol. of EMITFSI was added and stirring was achieved 2 more minutes. The amount of ionic liquid also was found out elsewhere to be an optimum in term of mechanical behavior and ionic conductivity. ${ }^{24}$ Sol+IL mixture was casted in sealed containers and kept for 1 day at RT for gelation and was then aged in vacuum oven during 4 days at $120^{\circ} \mathrm{C}$ to remove sol-gel reaction byproducts (water, alcohol ... ) and residual FA. ${ }^{23,24}$ Monolithic pieces of wet gels were then obtained (see Figure 1b). Such silicabased ionogels could be described as two interconnecting networks of silica and ionic liquid at nanometer scale. The trapped-IL experiences a large interface with pore walls which is expected to modify its microscopic structure and dynamics compare to the bulk phase. ${ }^{25,26}$ Clear and crack-free gels were obtained tuning silane to acid volume ratio to $4: 5 .^{27}$ Volume ratios are reported in Figure 1a.

Electrochemical tests were carried out using an Autolab PGSTAT128N (Metrohm, Switzerland). A RHD cell (RHD, Germany) was used for the tests which enable to finely control the cell temperature from -35 up to $80^{\circ} \mathrm{C}$. All the cells were assembled in a MBraün glove box $\left(\mathrm{O}_{2}\right.$ and $\mathrm{H}_{2} \mathrm{O}$ contents lower than $\left.0.1 \mathrm{ppm}\right)$. Ionic conductivity vs temperature of the synthesized gels was measured through Electrochemical Impedance Spectroscopy using two gold current collectors. Supercapacitor cells were assembled using gold platinum current collectors on which activated carbon based active material films were casted. Active material was made of $95 \mathrm{wt} \%$ of PICACTIF SC, which is a standard high specific surface area activated carbon $\left(2300 \mathrm{~m}^{2} / \mathrm{g}\right),{ }^{28}$ and $5 \mathrm{wt} \%$ of PTFE (60 wt $\%$ PTFE in water DuPont Nemours, France) ${ }^{29}$ Few droplets of Silane-IL mixture was deposited onto the electrodes and then sandwiched. The gel formation was obtained following procedure previously described. This technique is really simple and offers a possible way to work with a large amount of active material (from few $\mathrm{mg}$ up to $15 \mathrm{mg} / \mathrm{cm}^{2}$ ). ${ }^{28}$ After aging, the ionogel is placed in a RHD cell for further electrochemical tests.

\section{Results and Discussion}

Ionic conductivity.- Figure 2 shows the change of conductivity of the ionogel with temperature (Arrhenius plot) between $-35^{\circ} \mathrm{C}$ and $80^{\circ} \mathrm{C}$. First it should be noted that ionogel conductivity $(4.7 \mathrm{mS} / \mathrm{cm}$ at $\left.20^{\circ} \mathrm{C}\right)$ is close to that of neat IL $(8 \mathrm{mS} / \mathrm{cm}$ at RT). Such conductivity

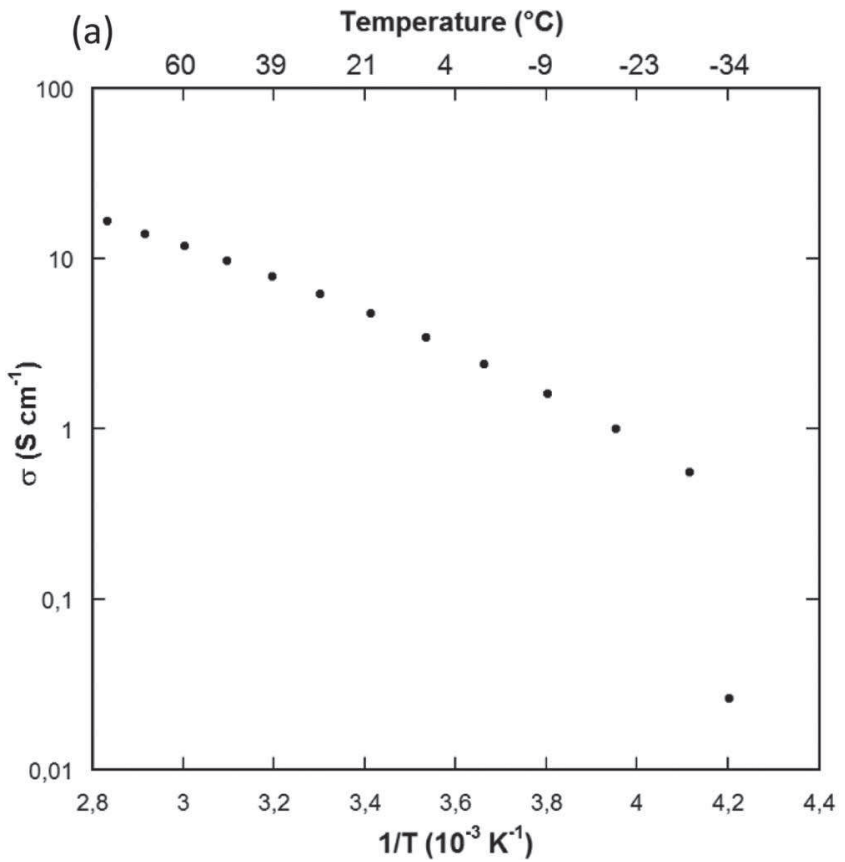

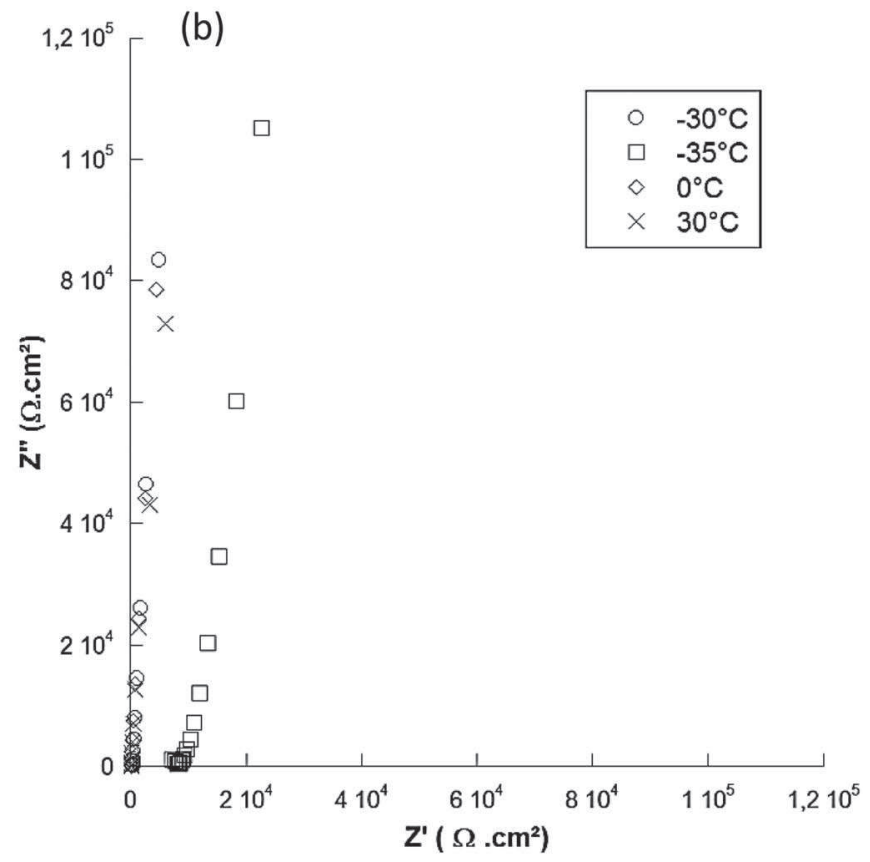

Figure 2. (a) Arhenius plot of ionogel between $-35^{\circ} \mathrm{C}$ and $80^{\circ} \mathrm{C}$. Conductivities were calculated from high frequency intercept with real axis of the Nyquist Plots; exemple are given in 2(b). 

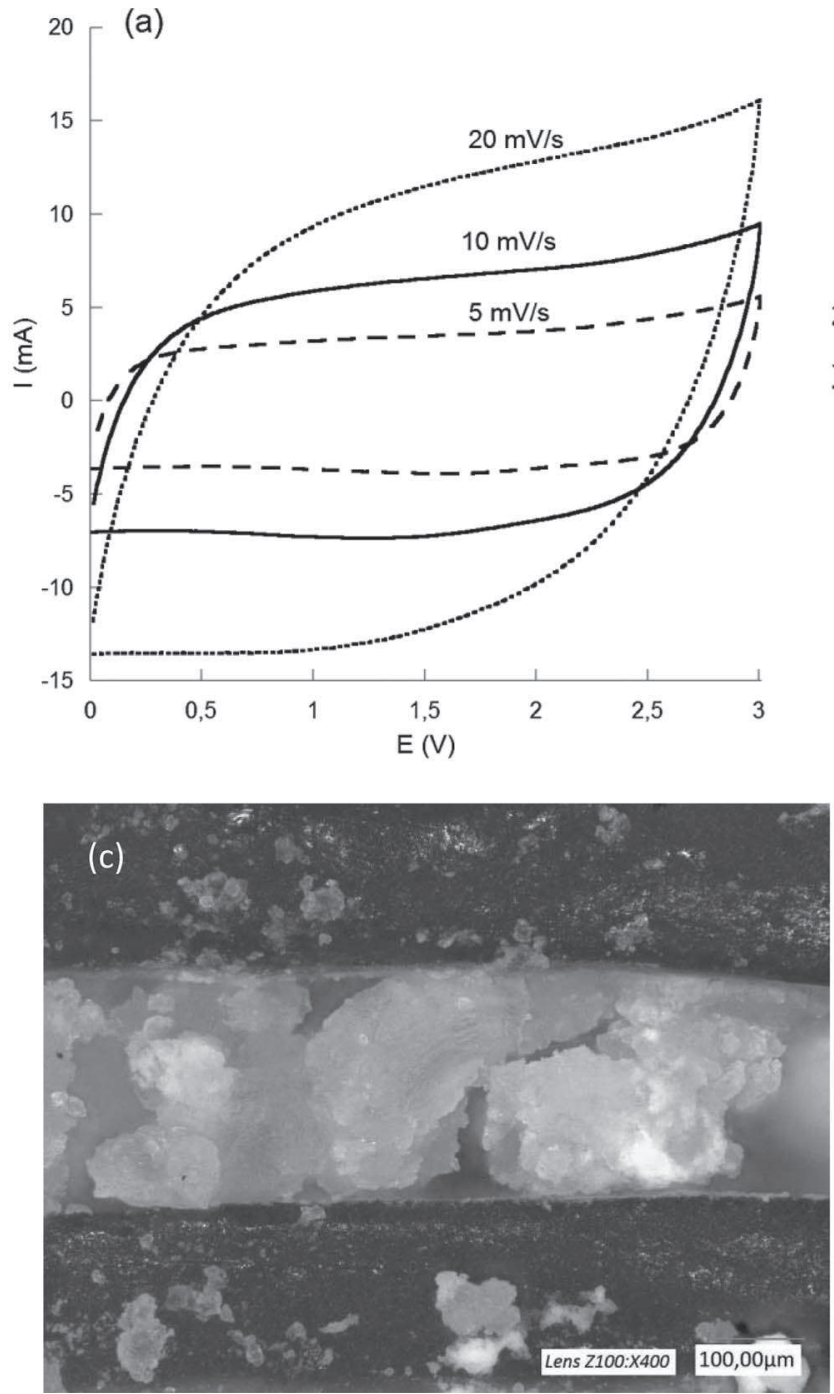

(b)
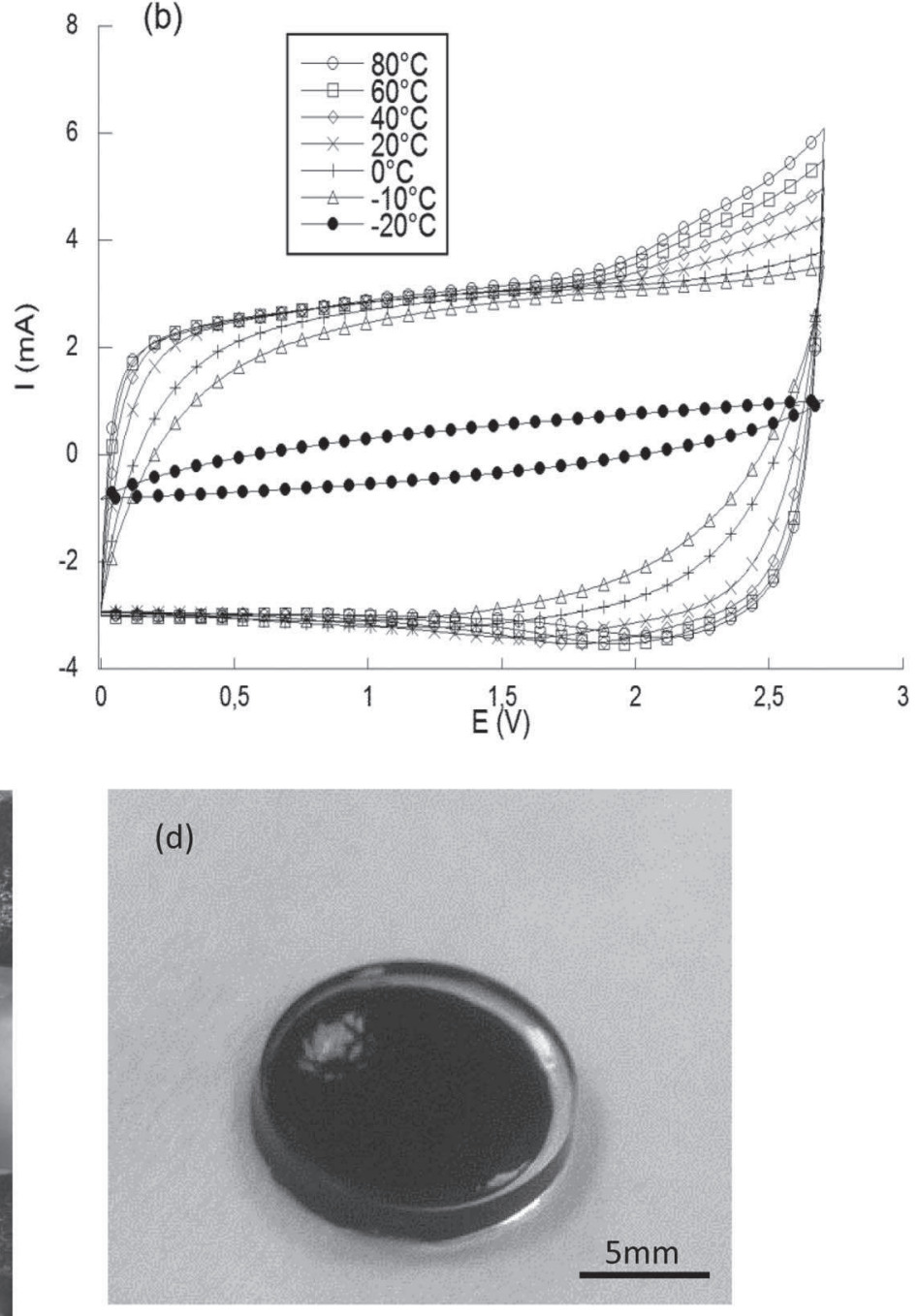

Figure 3. (a) $3 \mathrm{~V}$ operating voltage Cyclic Voltammetry of ionogel sample at 5,10 and $20 \mathrm{mV} / \mathrm{s} \mathrm{scan}$ rate. (b) $\mathrm{CV}$ at different temperature (from -20 to $+80^{\circ} \mathrm{C}$ ). (c) Optical microscopy picture of an ionogel based activated carbon sandwich. (d) Picture of a gelled activated carbon electrode.

values match with the requirement needed for use as electrolyte free solvent. ${ }^{30}$

Actually, from -30 to $80^{\circ} \mathrm{C}$ the conductivity follows an Arrhenius plot with an activation energy of $2.6 \mathrm{~kJ} / \mathrm{mole}$. Such low activation energy confirms an appreciate ion mobility. Moreover, these results show that even below the ionic liquid freezing point $\left(-16.1^{\circ} \mathrm{C}\right)$, the ionogel solvent free is still conductive at $-30^{\circ} \mathrm{C}$; this is assumed to be linked with the confinement of EMITFSI. The crystallization temperature shifts from $-16^{\circ} \mathrm{C}$ down to $-30^{\circ} \mathrm{C}$; at $-35^{\circ} \mathrm{C}$ the crystallization process starts. Such a behavior has been reported elsewhere by Le Bideau et al. ${ }^{31,25}$

Ionogel-based supercapcitor: design and efficiency:- An all solid supercapacitor was tested by Cyclic Voltammetry (CV) at $5 \mathrm{mV} / \mathrm{s}$ between 0 and $3 \mathrm{~V}$ at RT. The rectangular shaped cyclic volatammetry induces capacitive storage with the porous carbon. A gravimetric capacitance close to $80 \mathrm{~F} / \mathrm{g}$ was calculated from the $\mathrm{CV}$, which is close to the one obtained in liquid electrolyte..$^{29}$ Although the increase of the sweep rate, up to $20 \mathrm{mV} / \mathrm{s}$, led to a distortion of the $\mathrm{CV}$ because of the ohmic drop, the capacitive signature is still preserved, associated with a limited loss $(\sim 20 \%)$, evidencing decent power capability.

Figure $3 \mathrm{a}$ shows the $\mathrm{CVs}$ recorded at $5 \mathrm{mVs}$ between $-20^{\circ} \mathrm{C}$ and $80^{\circ} \mathrm{C}$, after one hour stabilization at set temperature. The capacitive behavior is kept down to temperature as low as $-10^{\circ} \mathrm{C}$, while keeping a constant capacitance in this temperature range. These results are consistent with Figure $2 b$ that showed that ionic mobility was still high at such low temperature. The low capacitance at $-20^{\circ} \mathrm{C}$ is assumed to come from the crystallization of the IL in the confined pores of the carbon structure. ${ }^{31}$ Nevertheless, lower working temperature (at least down to $-30^{\circ} \mathrm{C}$ ) could be reached using more open carbon structures, like it has been already shown. ${ }^{30}$ Figure $3 \mathrm{c}$ showing an optical cross section microscopy picture using an optical Keyence VHX1000 digital microscopy. The cracks came from the cut. The specific capacitance of the PICACTIF SC activated carbon is around $95 \mathrm{~F} / \mathrm{g}$ in neat EMITFSI. ${ }^{28,32}$ Our device shows for a $3 \mathrm{~V}$ operating cell voltage a $80 \mathrm{~F} / \mathrm{g}$ gravimetric capacitance at RT which is not so far from the value obtain in liquid state.

Figure 4a shows the Nyquist plots at a bias cell voltage of $0 \mathrm{~V}$ with a signal amplitude of $5 \mathrm{mV}$ RMS, from $1 \mathrm{MHz}$ down to $0.01 \mathrm{~Hz}$. At very low frequency, the quasi-vertical line observed shows the capacitive behavior of the system. The transition between these two regimes, indicated by a linear Warburg-like behavior, originates from the porous network of the activated carbon. This region corresponds to the "penetration" of the electrolyte into the porous structure of the electrode. Once the total capacity of electrode is reached, the imaginary part sharply increases. The difference between the high-frequency resistance and the extrapolation of the low frequency linear capacitive behavior on the real part axis defines the electrolyte resistance 
(a)

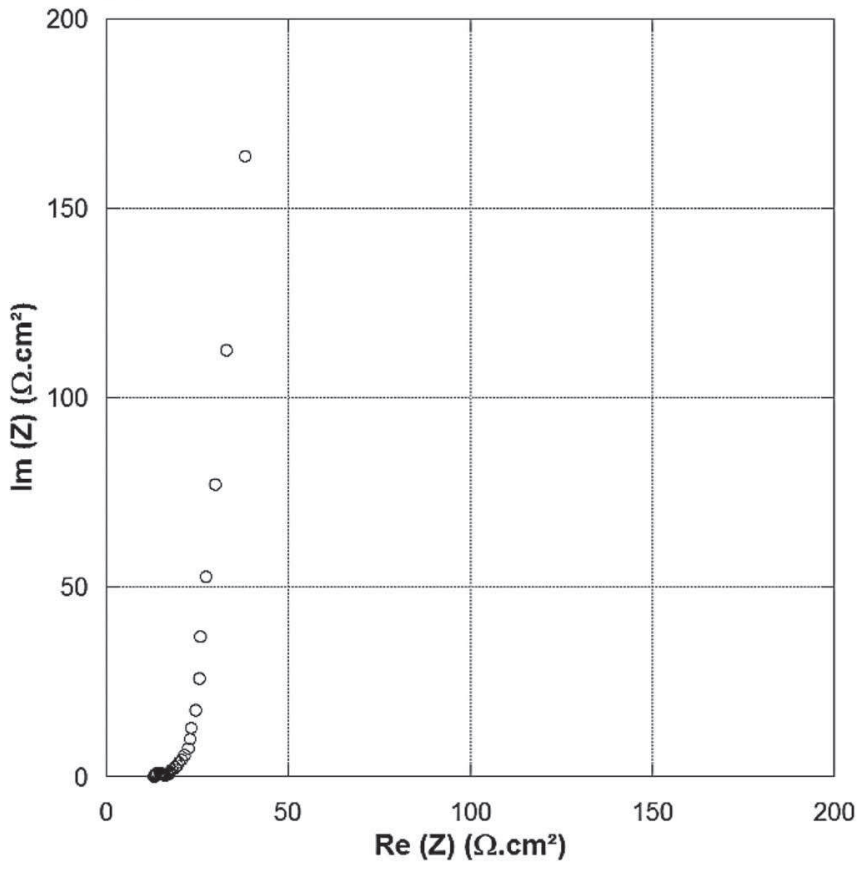

(b)

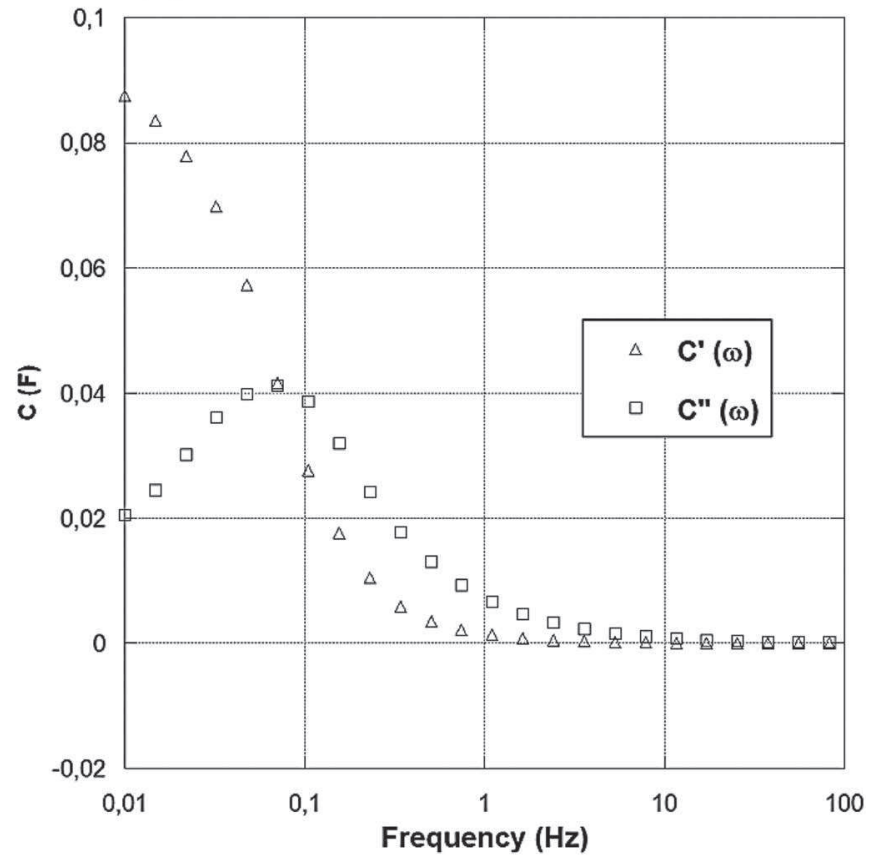

Figure 4. (a) EIS Plot of ionogel-based activated carbon supercapacitor. (b) Impedance plot using complex capacitance model.

inside the carbon porous network. The frequency behavior of the cell was analyzed using a complex capacitance model, based on the modeling of the capacitance in real part $C^{\prime}(\omega)$ and imaginary part $C^{\prime \prime}(\omega)$, both functions of the frequency:

$$
\begin{aligned}
& C^{\prime}=-Z^{\prime \prime} / \omega Z^{2} \\
& C^{\prime \prime}=-Z^{\prime} / \omega Z^{2}
\end{aligned}
$$

Where $C^{\prime}$ is the real part and $C^{\prime \prime}$ is the imaginary part of the capacitance C. $\omega$ is the angular frequency and $\mathrm{Z}$ stands for the impedance modulus.

Figure $4 \mathrm{~b}$ shows the change of the real part of the capacitance $\mathrm{C}^{\prime}$ with frequency. The graph shows a transition from purely resistive behavior at high frequency (phase angle close to 0 ) to purely capacitive behavior at low frequency (around $0.1 \mathrm{~Hz}$ ). The whole capacitance of the electrode is not reached even at around $0.01 \mathrm{~Hz}$. The relaxation time $\tau_{0}$ in this system is $10 \mathrm{~s}$, which can be calculated from $\tau_{0}=1 / \mathrm{f}_{0}$, where $f_{0}$ is the frequency corresponding to the maximum of the curve of $\mathrm{C}^{\prime \prime}$ vs. $\mathrm{f}$, in our case $\mathrm{f}_{0}=0.1 \mathrm{~Hz}^{28}$ Despite the use of a solid state electrolyte, this value is in the same range as the one reported for liquid electrolytes, thus demonstrating the interest of ionogel electrolytes for supercapacitors. $^{28}$

\section{Conclusions}

In this paper were presented the results obtained with carboncarbon ionogel-based supercapacitor exhibiting decent capacitive behavior over a wide temperature range $\left(-30^{\circ} \mathrm{C}+80^{\circ} \mathrm{C}\right)$, thanks to conductivity of synthetized ionogel $\left(4.7 \mathrm{~ms} / \mathrm{cm}\right.$ at $\left.20^{\circ} \mathrm{C}\right)$. Such temperature stability was ascribed to ionic liquid confinement. Assembled devices with such ionogel led to achieve all solid supercapacitor with attractive real capacitance higher than $150 \mathrm{mF} / \mathrm{cm}^{2}$ per electrode at 1 $\mathrm{mV} / \mathrm{s}$ and stable up to $3 \mathrm{~V}$ cell voltage. Such devices could efficiently replace liquid-based systems for improving the safety, corrosion and packaging issues of supercapacitors.

\section{References}

1. P. Simon and Y. Gogotsi, Nature Materials, 7, 845 (2008).

2. P. Simon, Y. Gogotsi, and B. Dunn, Science, 343, 1210 (2014).
3. W. Sugimoto, K. Yokoshima, Y. Murakami, and Y. Takasu, Electrochimica Acta, 52, 1742 (2006).

4. F. Béguin, V. Presser, A. Balducci, and E. Frackowiak, Advanced Materials, 26, 2219 (2014).

5. V. Augustyn, P. Simon, and B. Dunn, Energy \& Environmental Science, 7, 1597 (2014).

6. T. Brousse et al., Journal of Power Sources, 173, 633 (2007).

7. J. R. Miller and P. Simon, Science, 321, 651 (2008).

8. J. Chmiola, Science, 313, 1760 (2006).

9. C. Largeot et al., Journal of the American Chemical Society, 130, 2730 (2008).

10. M. Armand, F. Endres, D. R. MacFarlane, H. Ohno, and B. Scrosati, Nature Materials, 8, 621 (2009).

11. A. Laheäär, A. Jänes, and E. Lust, Electrochimica Acta, 56, 9048 (2011)

12. E. Perricone et al., Journal of Power Sources, 239, 217 (2013).

13. A. Brandt, P. Isken, A. Lex-Balducci, and A. Balducci, Journal of Power Sources, 204, 213 (2012).

14. A. Brandt and A. Balducci, Journal of the Electrochemical Society, 159, A2053 (2012).

15. C. Largeot, P. L. Taberna, Y. Gogotsi, and P. Simon, Electrochemical and Solid-State Letters, 14, A174 (2011).

16. M. Mastragostino et al., ECS 1, 55 (2006).

17. A. Fernicola, B. Scrosati, and H. Ohno, Ionics, 12, 95 (2006).

18. D. R. MacFarlane et al., Energy \& Environmental Science, 7, 232 (2014).

19. L. Timperman, H. Galiano, D. Lemordant, and M. Anouti, Electrochemistry Communications, 13, 1112 (2011).

20. L. Timperman, F. Beguin, E. Frackowiak, and M. Anouti, Journal of the Electrochemical Society, 161, A228 (2013).

21. M. Schroeder et al., Journal of the Electrochemical Society, 160, A1753 (2013).

22. M. Brachet, T. Brousse, and J. Le Bideau, ECS Electrochemistry Letters, 3, A112 (2014).

23. K. G. Sharp, J Sol-Gel Sci Technol, 2, 35 (1994).

24. M.-A. Néouze, J. L. Bideau, P. Gaveau, S. Bellayer, and A. Vioux, Chem. Mater, 18, 3931 (2006).

25. A. Vioux, L. Viau, S. Volland, and J. Le Bideau, Comptes Rendus Chimie, 13, 242 (2010).

26. A. K. Gupta, M. P. Singh, R. K. Singh, and S. Chandra, Dalton Transactions, 41, 6263 (2012).

27. B. S. Dunn, C. O. Chui, A. P. Jacob, D. Membreno, and L. Smith, (2014) Patent: US20140035098

28. P. L. Taberna, P. Simon, and J. F. Fauvarque, Journal of The Electrochemical Society, 150, A292 (2003).

29. J. Gamby, P. L. Taberna, P. Simon, J. F. Fauvarque, and M. Chesneau, Journal of Power Sources, 101, 109 (2001).

30. W.-Y. Tsai et al., Nano Energy, 2, 403 (2013).

31. J. L. Bideau, P. Gaveau, S. Bellayer, M.-A. Néouze, and A. Vioux, Phys. Chem. Chem. Phys., 9, 5419 (2007).

32. M. Lazzari, M. Mastragostino, and F. Soavi, Electrochemistry Communications, 9, 1567 (2007). 